\title{
High production of ectoine from aspartate and glycerol by use of whole-cell biocatalysis in recombinant Escherichia coli
}

\author{
Yong-Zhi He ${ }^{1,2}$, Jiao Gong ${ }^{1}$, Hai-Ying Yu' ${ }^{1}$ Yong Tao ${ }^{3}$, Shan Zhang ${ }^{1^{*}}$ and Zhi-Yang Dong ${ }^{1 *}$
}

\begin{abstract}
Background: Recently, the compatible solute 1, 4, 5, 6-tetrahydro-2-methyl-4-pyrimidinecarboxylic acid (ectoine) has attracted considerable interest due to its great potential as a protecting agent. To overcome the drawbacks of high salinity in the traditional bioprocess of ectoine using halophilic bacteria, various attempts have been made to engineer ectoine biosynthesis in nonhalophilic bacteria. Unfortunately, the yields of ectoine in these producers are still low and hardly meet the demands of large scale production. In this paper, the whole-cell biocatalytic process using aspartate and glycerol as substrates was tried for high production of ectoine in nonhalophilic bacteria.

Results: The ectoine genes ectABC from the halophilic bacterium Halomonas elongata were successfully introduced into Escherichia coli K-12 strain BW25113 under the arabinose-inducible promoter. To our delight, a large amount of ectoine was synthesized and excreted into the medium during the course of whole-cell biocatalysis, when using aspartate and glycerol as the direct substrates. At the low cell density of $5 \mathrm{OD} / \mathrm{mL}$ in flask, under the optimal conditions (100 mM sodium phosphate buffer (pH 7.0), $100 \mathrm{mM}$ sodium aspartate, $100 \mathrm{mM} \mathrm{KCl}$ and $100 \mathrm{mM}$ glycerol), the concentration of extracellular ectoine was increased to $2.67 \mathrm{mg} / \mathrm{mL}$. At the high cell density of $20 \mathrm{OD} / \mathrm{mL}$ in fermentor, a maximum titre of $25.1 \mathrm{~g} / \mathrm{L}$ ectoine was achieved in $24 \mathrm{~h}$. Meanwhile, the biomass productivity of ectoine is as high as $4048 \mathrm{mg}$ per gram dry cell weight $\left(\mathrm{g} \mathrm{DCW}^{-1}\right.$, which is the highest value ever reported. Furthermore, it was demonstrated that the same batch of cells could be used for at least three rounds. Finally, a total yield of $63.4 \mathrm{~g}$ ectoine was obtained using one litre cells.

Conclusion: Using aspartate and glycerol as the direct substrates, high production of ectoine was achieved by the whole-cell biocatalysis in recombinant $E$. coli. Multiple rounds of whole-cell biocatalysis were established to further improve the production of ectoine. Our study herein provided a feasible biosynthesis process of ectoine with potential applications in large-scale industrial production.
\end{abstract}

Keywords: Ectoine, Halomonas elongata, Escherichia coli, Whole-cell biocatalysis, Aspartate, Glycerol

\section{Background}

To survive in salty environments, halophilic organisms have developed two different strategies to maintain osmotic balance. Some halophiles accumulate inorganic salts in the cytosol to counterbalance the high extracellular salt concentrations [1,2]; while some halophiles synthesize small organic molecules called compatible solutes as osmotic counterweights [3]. So far, many types of compatible solutes have been found, which can be

\footnotetext{
*Correspondence: Zhangshan1304@gmail.com; dongzy@im.ac.cn

'State Key Laboratory of Microbial Resources, Institute of Microbiology,

Chinese Academy of Sciences, Beijing 100101, China

Full list of author information is available at the end of the article
}

divided into different classes by their structures, such as sugars, polyols, methylamines, betaines, amino acids and their derivatives. Ectoine (1, 4, 5, 6-tetrahydro-2-methyl4-pyrimidinecarboxylic acid), a heterocyclic amino acid, is one of the most widely used compatible solutes in nature. It was discovered originally in the extremely halophilic phototrophic bacterium Ectothiorhodospira halochloris [4]. In addition to be functional as an osmotic counterweight, ectoine was found to be capable of protecting proteins, nucleic acids, cell membrane and even the whole cells against denaturation caused by heating, freezing, drying, or chemical agents [5-7]. For these properties, ectoine is currently produced for 
versatile commercial applications in the pharmaceutical industry. It can also be used as protein stabiliser, PCR enhancer, drying protective agent for microorganisms, and cosmetic additive [8-10]. The biosynthetic pathway of ectoine has been fully elucidated [11,12]. It shares the first two enzymatic steps with the biosynthesis of amino acids of the aspartate family: the synthesis of Laspartate-phosphate through the ATP-dependent phosphorylation of L-aspartate by aspartate kinase (Ask), and the synthesis of L-aspartate-beta-semialdehyde through an NADPH-dependent reaction by L-aspartatebeta-semialdehyde-dehydrogenase (Asd). Ecotine is then formed by a specific route composed of three reactions. L-aspartate-beta-semialdehyde is first transaminated to generate L-2, 4-diaminobutyric acid (DABA) by DABA transaminase (EctB), which is then converted to $\mathrm{N}-\gamma$ acetyldiaminobutyric acid by DABA- $\mathrm{N}-\gamma$-acetyltransferase (EctA). A cyclic condensation reaction catalysed by ectoine synthase (EctC) finally leads to the formation of tetrahydropyrimidine L-ectoine. In some organisms, ectoine can be further converted to hydroxyectoine by ectoine hydroxylase (EctD) (Figure 1). So far, the ect $A B C$

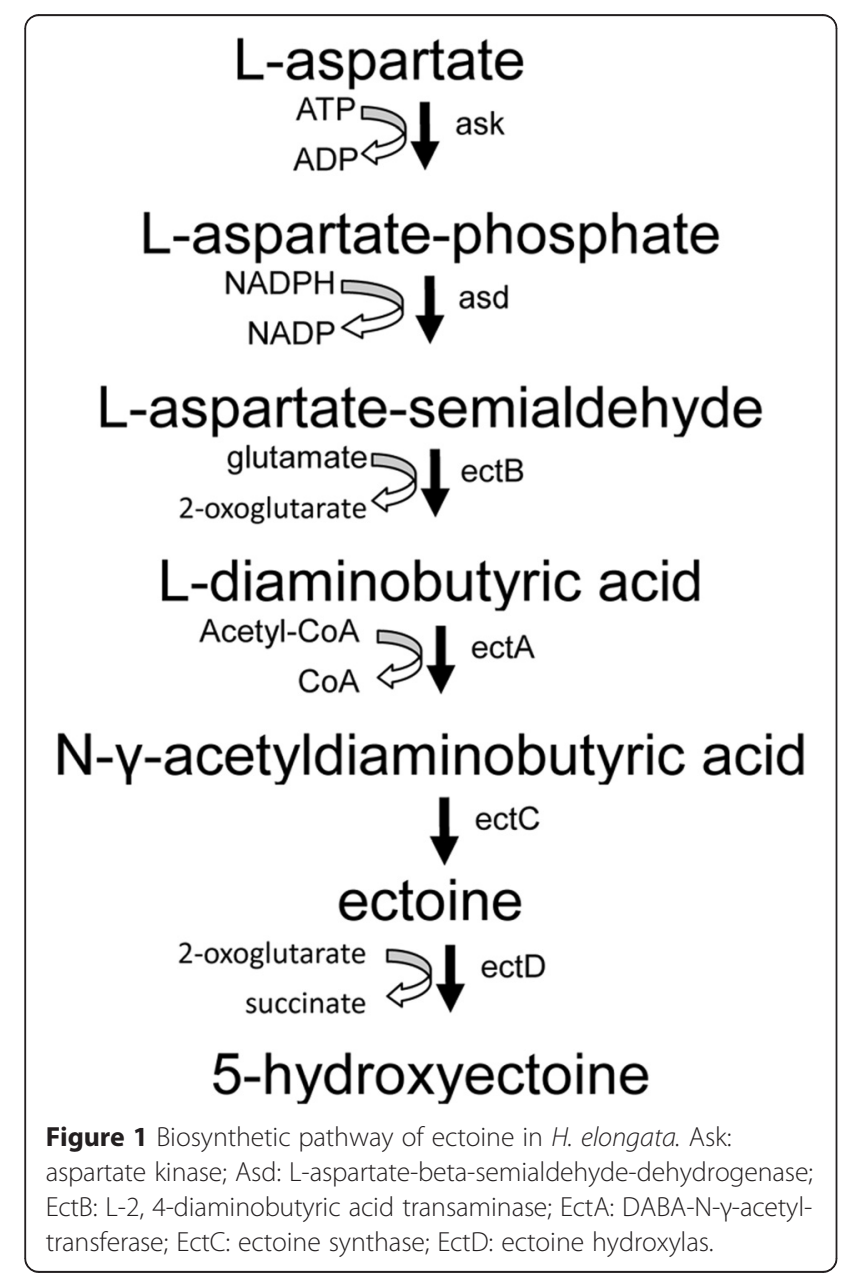

gene cluster involved in the biosynthesis of ectoine has been founded and characterised from many microorganisms [13].

It was reported that many halophilic and halotolerant microorganisms could synthesize ectoine in salt stress environments [10]. To meet the increasing commercial demand of ectoine, the bacterial processes for ectoine production has been improved in the past two decades. A technical bioprocess called "bacterial milking" was developed using the halophilic eubacterium $H$. elongata [14], which involved a cyclic increase and decrease of the salt concentration for ectoine synthesis and secretion, respectively. By this process the maximum yield of ectoine could reach $155 \mathrm{mg} / \mathrm{g}$ DCW. In another work, Fallet et al. integrated the process of synthesis and secretion by utilising two continuous bioreactors. Through process optimisation, the yield of ectoine and hydroxyectoine reached 540 and $400 \mathrm{mg} / \mathrm{g}$ DCW respectively, which should be the highest level reported so far [15]. Although "bacterial milking" is currently the most successful method for ectoine production, some drawbacks of this method is inevitable including the corrosion of equipment, the reduction of cell growth rate and the difficulty of downstream processing due to the discontinuous production scheme and high salt concentration [16]. To overcome these shortages, Halomonas salina, a halophilic bacterium that can grow and excrete ectoine in a lower salt concentration, was chosen for ectoine production using monosodium glutamate as a carbon and nitrogen source in $0.5 \mathrm{M} \mathrm{NaCl}$ batch fermentors. An ectoine titre of $6.9 \mathrm{~g} / \mathrm{L}$ was obtained, and the productivity was $7.9 \mathrm{~g} / \mathrm{L} /$ day [17]. In addition, heterologous expression of the ectoine biosynthetic pathway in E. coli has been developed as an alternative strategy. Multiple ectoine biosynthetic gene clusters from different halophiles were introduced into $E$. coli [18-21]. When those ectoine clusters were under the control of the natural regulatory promoters, production of ectoine could only be detected in the recombinant $E$. coli strains in cells, but not extracellularly. The ectoine genes of Chromohalobacter. salexigens were expressed in E. coli $\mathrm{DH} 5 \alpha$ under the control of an inducible tet promoter. After an induction time of $160 \mathrm{~h}$ in bioreactor cultivation, the recombinant $E$. coli strain could synthesis $6 \mathrm{~g} / \mathrm{L}$ ectoine with a space-time yield of $40 \mathrm{mg} / \mathrm{L} / \mathrm{h}$, in which the vast majority of ectoine was excreted [16]. Recently, ectoine synthesis clusters from halophiles were also expressed in other model microorganisms. A microbial cell factory was obtained by introduction of a codon-optimised ectABCD gene cluster from Pseudomonas stutzeri into Corynebacterium glutamicum, which could produce ecotine at $6.7 \mathrm{~g} / \mathrm{L} /$ day [22]. In another report, four hydroxyectoine biosynthesis genes from $H$. elongata were integrated into the genome of Hansenula polymorpha, 
and hydroxyectoine synthesis at the gram per litre scale was achieved [23].

In this study, a recombinant $E$. coli strain was constructed by overexpression of the ect $A B C$ gene cluster from $H$. elongata under the control of an inducible promoter. Using a whole-cell biocatalytic method, the recombinant cells could synthesize and secrete ectoine with high efficiency. The results highlight the promise of large-scale ectoine production with a more convenient and effective method.

\section{Results}

\section{Cloning and expression of ectoine genes in $E$. coli}

The ectoine operon of $H$. elongata was cloned and sequenced. The sequence of the ect $A B C$ gene cassette was $2432 \mathrm{bp}$ in length and consistent with the reported sequences. E. coli transformants harbouring pBADectABC were induced with $\mathrm{L}$-arabinose. SDS-PAGE of the cell lysate revealed three clear bands with molecular masses of $25 \mathrm{kDa}, 48 \mathrm{kDa}$ and $18 \mathrm{kDa}$, that were correspond to EctA, EctB and EctC from $H$. elongata respectively (Figure 2). Those bands were identified as EctA (77\% sequence coverages, gi|503097538), EctB (67\% sequence coverages gi|503097539) and EctC (79\% sequence coverages gi|503097540) from $H$. elongata DSM 2581 by MALDI-TOF mass spectrometry, respectively. The results of SDS-PAGE and mass spectrometric indicated that the ectABC gene cassette from $H$. elongata was successfully expressed in E. coli K strain BW25113.

\section{Bioconversion and excretion of ectoine from recombinant E. coli}

Ectoine was successfully synthesized using a whole-cell biocatalytic method. In the reaction mixture, aspartate provided the substrate to synthesize L-aspartate-betasemialdehyde, and glycerol could provide energy and the acetyl group for ectoine synthesis. $\mathrm{KCl}$ was added to the mixture to improve the activity and stability of ectB. Analyzed by HPLC, there appeared a new peak possessing the same retention time as the authentic ectoine in the tested samples (Figure 3A, B). After $24 \mathrm{~h}$, the concentration of extracellular ectoine reached $1.56 \mathrm{mg} / \mathrm{mL}$. To confirm that ectoine was really synthesized and excreted into the conversion solution, LC-MS and LC-MS/MS analyses were performed. Analyzed by LC/triple quadrupole mass spectrometry, for the compound in the conversion mixture, the retention time, the spectra signal of LC-MS anslysis (pseudo-molecular ion at $\mathrm{m} / z$ 143) (Figure 3C, D) and of LC-MS/MS analysis (product ions at $m / z 143.3,97.0,68.2,55.9$, and 44.0) (Figure 3E, F) were all in agreement with the data of the authentic ectoine. Therefore, the compound in the conversion mixture was identified as ectoine.

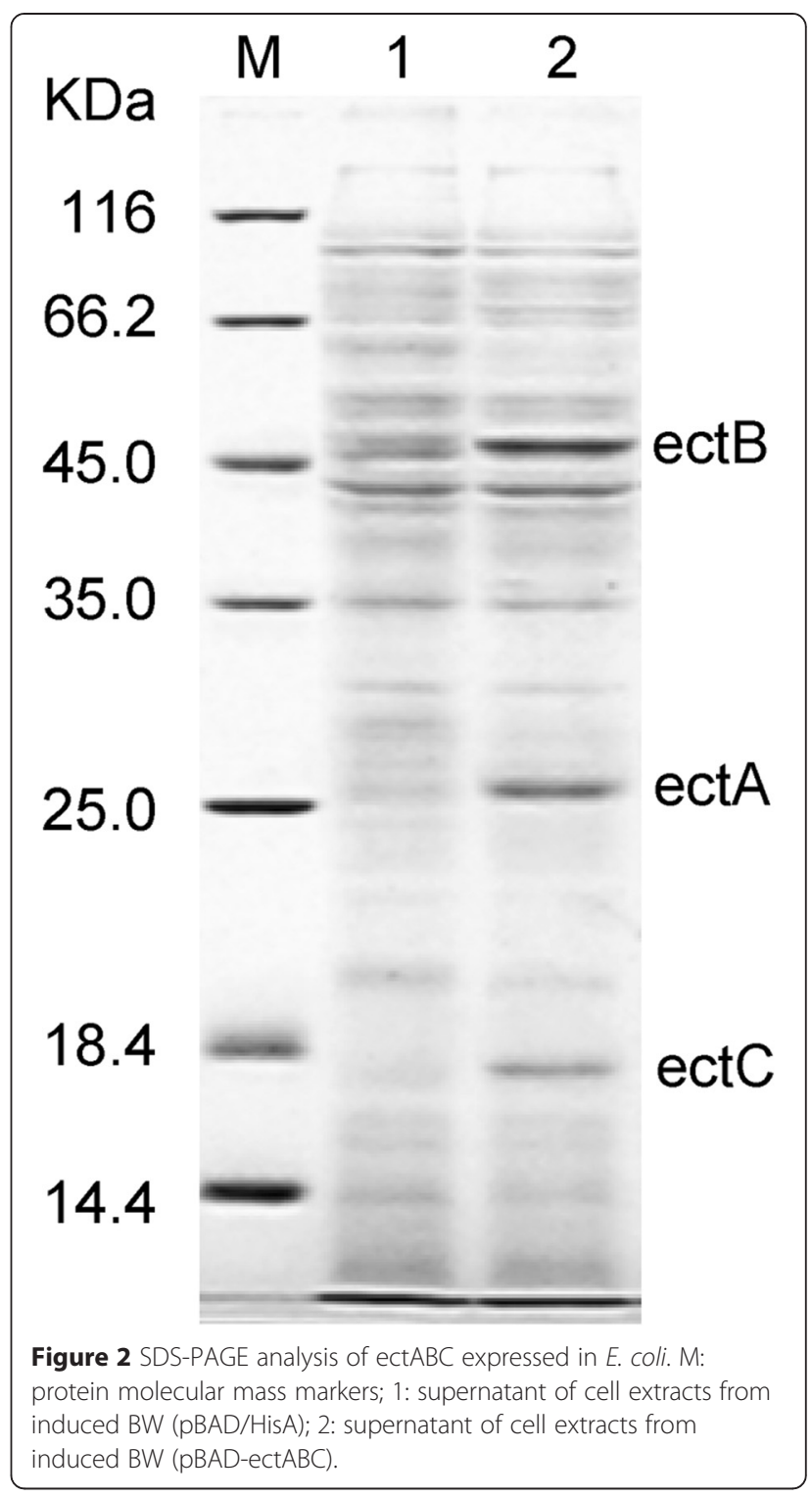

\section{Optimization of ectoine bioconversion}

To determine the optimal conditions for ectoine production, multiple factors were investigated in whole-cell biocatalytic experiment in flask with a cell density of $5 \mathrm{OD} /$ $\mathrm{mL}$. The results of sodium aspartate concentration experiment indicated that the optimal concentration range of sodium aspartate was between 100 to $200 \mathrm{mM}$, over $2.25 \mathrm{mg} / \mathrm{mL}$ of extracellular ectoine was detected at these concentrations. Under a higher concentration of $300 \mathrm{mM}$ sodium aspartate, only $1.23 \mathrm{mg} / \mathrm{mL}$ of ectoine was excreted into the mixture (Figure $4 \mathrm{~A}$ ). In $\mathrm{KCl}$ concentration comparative test, low concentration of $\mathrm{KCl}$ between 50 to $200 \mathrm{mM}$ can significantly improve the production of ectoine. A maximum ectoine production $(2.59 \mathrm{mg} / \mathrm{mL})$ was obtained with a $\mathrm{KCl}$ concentration of $100 \mathrm{mM}$. However, in the presence of $300 \mathrm{mM} \mathrm{KCl}$, the 




production of ectoine decreased sharply to only $1.25 \mathrm{mg} / \mathrm{mL}$ (Figure 4B). The effect of temperature was investigated between 25 to $40^{\circ} \mathrm{C}$ (Figure $4 \mathrm{C}$ ). The results indicated that the highest yield was obtained at $30^{\circ} \mathrm{C}$. The effect of $\mathrm{pH}$ on ectoine production processed at range of $6.0 \sim 8.0$ indicated that the optimum pH was 7.0 (Figure 4D). In conclusion, the optimal reaction mixture in flask reaction was determined as follows: $100 \mathrm{mM}$ sodium phosphate buffer (pH 7.0), $100 \mathrm{mM}$ sodium aspartate, $100 \mathrm{mM} \mathrm{KCl}$, and
$100 \mathrm{mM}$ glycerol to form a cell suspension $\left(\mathrm{OD}_{600 \mathrm{~nm}}=5\right)$. The reactions were performed at $30^{\circ} \mathrm{C}, 200 \mathrm{rpm}$ for $24 \mathrm{~h}$. After the process optimization, the concentration of extracellular ectoine increased from $1.56 \mathrm{mg} / \mathrm{mL}$ to $2.67 \mathrm{mg} / \mathrm{mL}$.

In a flask reaction experiment using optimized conditions, the synthesis of ectoine and consumption of substrates during the whole bioconversion process were analysed in detail (Figure 5). The cells started to 

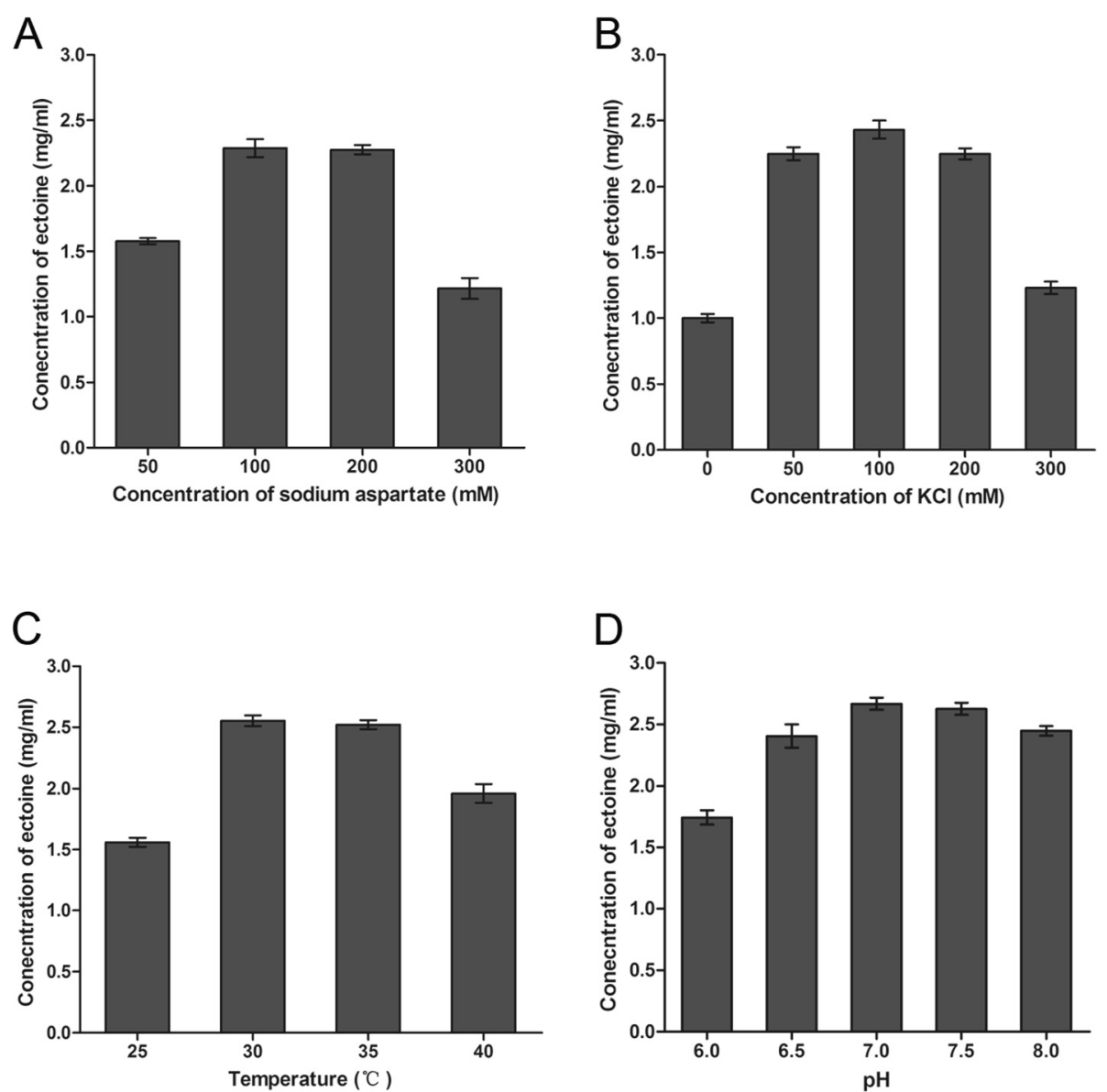

Figure 4 Optimization of ectoine production. The initial reaction mixture containing $100 \mathrm{mM}$ sodium phosphate buffer (pH 7.0), $50 \mathrm{mM}$ sodium aspartate, $50 \mathrm{mM} \mathrm{KCl}, 100 \mathrm{mM}$ glycerol, and recombinant E. coli cells of $5 \mathrm{OD} / \mathrm{mL}$ was incubated at $30^{\circ} \mathrm{C}$ for $24 \mathrm{~h}$. (A) Effects of sodium aspartate concentration on the production of ectoine. (B) Effects of $\mathrm{KCl}$ concentration on the production of ectoine (the concentration of sodium aspartate was $100 \mathrm{mM}$ ). (C) Effects of temperature on the production of ectoine (the concentrations of sodium aspartate and $\mathrm{KCl}$ were $100 \mathrm{mM}$ ). (D) Effects of $\mathrm{pH}$ on the production of ectoine (the concentrations of sodium aspartate and $\mathrm{KCl}$ were $100 \mathrm{mM}$ ). Error bars respresent standard deviations from triplicate biological replicates.

accumulate intracellular ectoine from the beginning of bioconversion, and after a reaction time of $4 \mathrm{~h}$, the ectoine was beginning to be excreted; after $20 \mathrm{~h}$, aspartate and glycerol were undetectable in the reaction mixture. After reacting for $24 \mathrm{~h}$, the concentration of extracellular ectoine increased to $2.71 \mathrm{mg} / \mathrm{mL}$. The corresponding extracellular ectoine concentration per gram dry cell weight reached $1748 \mathrm{mg} / \mathrm{g}$ DCW. During the whole reaction phase, the intracellular ectoine concentration was maintained at approximately $50 \mathrm{mg} / \mathrm{g} \mathrm{DCW}$.

\section{High production of ectoine using high density cells in a fermentor}

Ectoine bioconversion was also performed with higher density cells $\left(\mathrm{OD}_{600 \mathrm{~nm}}=20\right)$ in a fermentor (Figure 6A). When the reaction proceeded for $12 \mathrm{~h}$, the aspartate and glycerol were all consumed and feeding solution was added into the reaction system with a flow speed of
$25 \mathrm{~mL} / \mathrm{h}$. During the reaction phase, a significant quantity of ectoine was synthesized and excreted at a rate of $1046 \mathrm{mg} / \mathrm{L} / \mathrm{h}$. After a reaction time of $24 \mathrm{~h}$, the ectoine concentration reached $25.1 \mathrm{~g} / \mathrm{L}$ in the medium with a productive yield of $4048 \mathrm{mg} / \mathrm{g}$ DCW, which was significantly higher than that in flask reactions with low density cells $\left(\mathrm{OD}_{600 \mathrm{~nm}}=5\right)$. The ectoine bioconversion was successfully amplified in a fermentor, the yield of ectoine increased at least nine times compared with that in flasks.

\section{Production of ectione by multiple rounds of whole-cell biocatalysis}

To test whether the cells in the whole-cell biocatalysis could be used by multiple rounds, the process of wholecell biocatalysis using aspartate and glycerol as substrates was repeated for another two cycles with the same batch of $E$. coli cells. The results demonstrated that the extracellular ectoine concentrations of second and 


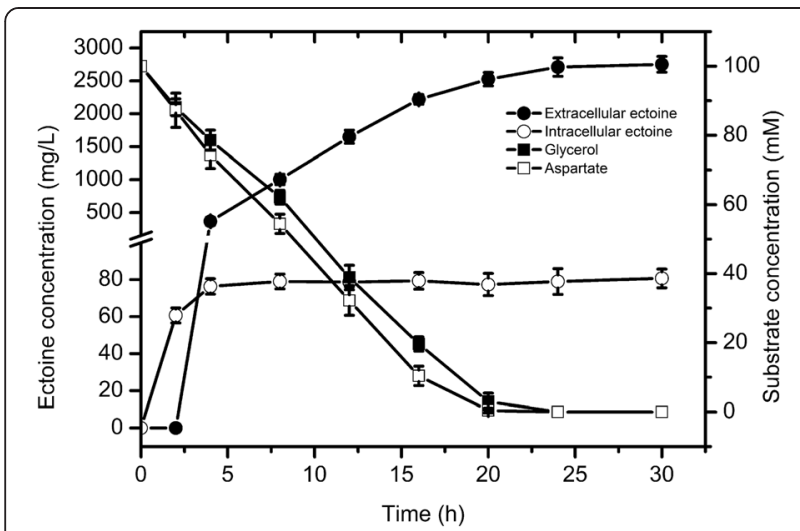

Figure 5 Time profiles of substrate concentration and ectoine production during flask-level bioconversion. An optimized reaction mixture containing $100 \mathrm{mM}$ sodium aspartate, $100 \mathrm{mM}$ glycerol, $100 \mathrm{mM} \mathrm{KCl}, 100 \mathrm{mM}$ sodium phosphate buffer (pH7.0) and recombinant $E$. coli cells of $5 \mathrm{OD} / \mathrm{mL}$ was used. The bioconversion reactions were performed at $30^{\circ} \mathrm{C}$ and $200 \mathrm{rpm}$ for $30 \mathrm{~h}$. Error bars represent standard deviations from triplicate biological replicates.

third round were $21.1 \mathrm{~g} / \mathrm{L}$ and $17.2 \mathrm{~g} / \mathrm{L}$, respectively. In other words, $84 \%$ and $69 \%$ of yields were achieved for the second and the third round of catalysis as compared to the first round, respectively (Figure 6B). Thus, multiple rounds of whole-cell biocatalysis are cost effective to further improve the production of ectione.

\section{Discussion}

In recent decades, whole-cell biocatalysis has been widely applied as an alternative to chemical methods for large-scale synthesis of chemicals because it is more environmentally friendly. Whole-cell biocatalysis allows cascades of enzymatic reactions that involve multiple enzymes, cofactors, and substrates; it can also help stabilise enzymes with the protective nature of cell envelopes and makes cofactor regeneration much easier [24]. E. coli
K12 is often used as a suitable cell factory in bioconversion because it is a nonpathogenic strain with a wellstudied genetic background and a powerful genetic tool system for metabolic engineering [25]. With a relatively well-developed fermentation, E. coli $\mathrm{K} 12$ is also easy to grow because of its short generation time and ability to synthesize everything needed for generating a completely new cell from low raw materials. Most advantageously, the $E$. coli genome sequence lacks an ectoine catabolic pathway [26], eliminating product degradation due to the reuse of ectoine as a carbon or nitrogen source. The biosynthesis of ectoine from L-aspartate is a complex process containing multiple enzymatic reactions in microorganisms. Using the above whole-cell biocatalytic method for the production of ectoine by recombinant $E$. coli has the potential to become the most promising method for commercial production.

As an industrial strain for ectoine production, the ectoine synthesis gene cluster of $H$. elongata has been cloned for more than 10 years [27], and the characteristics of ectoine biosynthetic enzymes have been described in detail [28]. However, there were still no reports describing heterologous ectoine synthesis in E. coli using the ect $A B C$ genes from this industrial strain. In our experiment, the ectABC gene cluster was first introduced into E. coli K strain BW25113 using the expression plasmid pBAD/HisA. Under the control of the ara promoter, all three enzymes corresponding to ectoine synthesis achieved soluble expression. Whole-cell biocatalysis was introduced into ectoine synthesis using aspartate and glycerol as substrates. The bioconversion was performed in shaking flasks and in a fermentor with cell concentrations of $5 \mathrm{OD} / \mathrm{mL}$ and $20 \mathrm{OD} / \mathrm{mL}$, respectively. In the fermentor the extracellular ectoine concentration reached $25.1 \mathrm{~g} / \mathrm{L}$ with a productive yield of $4048 \mathrm{mg} / \mathrm{g}$ DCW, which is markedly higher than the yield in the
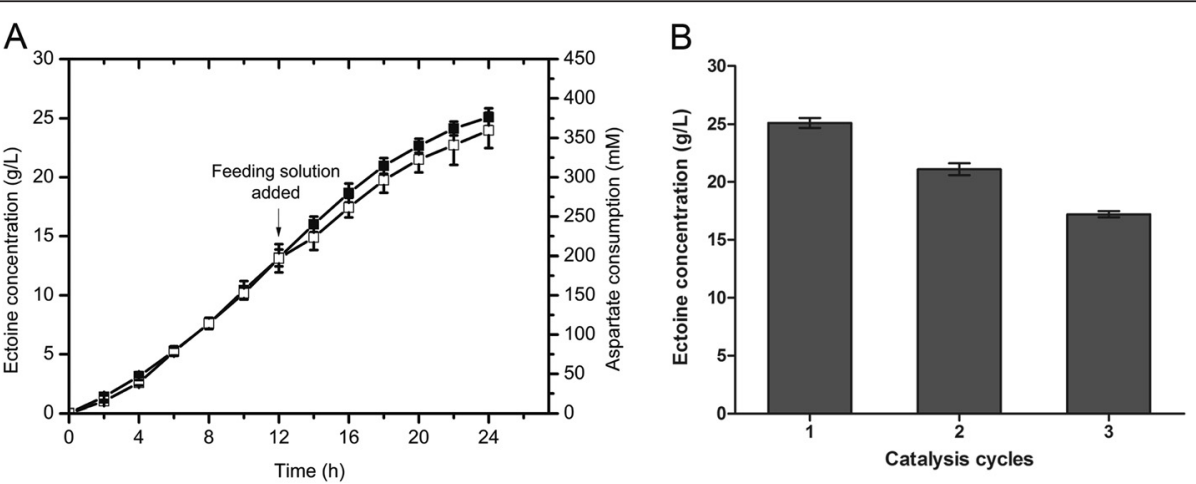

Figure 6 Ectoine production in fermentor. An initial reaction mixture containing $200 \mathrm{mM}$ sodium aspartate, $200 \mathrm{mM}$ glycerol, $100 \mathrm{mM}$ KCl, $100 \mathrm{mM}$ sodium phosphate buffer (pH7.0), and recombinant E. coli cells of $20 \mathrm{OD} / \mathrm{mL}$ was used. (A) Time profiles of aspartate consumption and ectoine excretion in fermentor. Legend: excreted ectoine (black squares), aspartate (white squares). After 12 h of bioconversion the feeding solution was added $(\downarrow)$ with a flow speed of $25 \mathrm{~mL} / \mathrm{h}$. (B) Repeated use of cells to synthesize ectoine in fermentor. Error bars respresent standard deviations from triplicate biological replicates. 
flask reaction of $1748 \mathrm{mg} / \mathrm{g}$ DCW. By controlling the $\mathrm{pH}$ and substrate feeding, the cell catalysis efficiency can be significantly improved in fermentor. The highest yield in history was achieved in C. salexigens (540 and $400 \mathrm{mg} / \mathrm{g}$ DCW for ectoine and hydroxyectoine respectively) [15], which is significantly lower than our ectoine yield (4048 mg/g DCW). After the first round of bioconversion, the cells were reused two more times, and a total yield of $63.4 \mathrm{~g}$ ectoine was obtained using one litre cells.

Ectoine is synthesized from aspartate-semialdehyde, the central intermediate in the synthesis of amino acids belonging to the aspartate family. Therefore, in recombinant $E$. coli, the synthesis rate of aspartate-semialdehyde determines the efficiency of ectoine conversion [18]. In the ectoine bioconversion system, sodium aspartate was added to the reaction mixture, and under the catalysis of $E$. coli endogenous Ask and Asd, aspartate could be converted to aspartate-semialdehyde more effectively than other substrates. In addition, under catalysis by glutamate-aspartate aminotransferase the amino group of aspartate could also be transferred to glutamate, which could provide the amino group for the transamination catalysed by EctB, the first reaction of the specific route for ectoine synthesis. The 2-oxoglutarate converted from glutamate by EctB could further supply substrate for the glutamate-aspartate transamination reaction to form glutamate. In summary, aspartate should be an ideal substrate for ectoine bioconversion because it can be used as both a synthetic precursor and an amino donor.

Another factor that may affect the efficiency of ectoine synthesis is the protein expression level of ectoine synthesis enzymes. In our experiment, under the control of the ara promoter all three enzymes of EctABC achieved overexpression, but in other reports with lower ectoine synthesis, not all of these three enzymes were detectable by SDS-PAGE $[16,20]$. We have also used pET28a with the T7 promoter to express EctABC in Bl21 (DE3), and in SDS-PAGE analysis only EctA and EctC were detectable, and there were no clear bands corresponding to EctB. The ectoine yield from the pET expression strain was only about one-third that of the pBAD expression strain (data not shown in this paper).

Our research confirmed that transgenic E. coli could efficiently synthesize and excrete ectoine into the medium. Although multiple ectoine biosynthetic genes have been expressed in E. coli, a similar finding has only been reported by Schubert et al. In their experiment, a high density culture of $20 \mathrm{~g} \mathrm{DCW} / \mathrm{L}$ was obtained in a fermentor. Following induction with anhydrotetracycline, they observed continuous excretion of ectoine at a rate of $2 \mathrm{mg} / \mathrm{g} \mathrm{DCW} / \mathrm{h}$, while the cellular level of ectoine stayed low at $5 \mathrm{mg} / \mathrm{g}$ DCW [16]. In our research, a lower density of cells with $6.45 \mathrm{~g} \mathrm{DCW} / \mathrm{L}\left(\mathrm{OD}_{600 \mathrm{~nm}}=20\right)$ was used to produce ectoine in a fermentor. During the synthetic phase, the average excretion rate of ectoine was $26.1 \mathrm{mg} / \mathrm{g} \mathrm{DCW} / \mathrm{h}$, whereas the cellular ectoine stayed at $50 \mathrm{mg} / \mathrm{g}$ DCW. Although E. coli does not synthesize ectoine, it was found that $E$. coli can pump ectoine out efficiently. At first, it was speculated that the proline transport systems, ProP and ProU, responsible for ectoine uptaking may also be functional in its excretion. However, the ProP and ProU deficient mutants could also pump ectoine out, indicating that there should be other efflux systems participating this process [26]. Moreover, Schubert et al. excluded the possibility that $E$. coli excretes ectoine by the unspecific mechanosensitive channels [16]. Further studies are demanded to elucidate the excretion mechanism of ectoine in E. coli.

\section{Conclusion}

The gene cluster of ectoine biosynthesis from the halophilic bacterium $H$. elongata was introduced into $E$. coli $\mathrm{K}$ strain and a powerful whole-cell biocatalytic system was constructed. Using aspartate and glycerol as the direct substrates, a large amount of ectoine was synthesized and excreted into the medium during the course of whole-cell biocatalysis. After the process optimization, the ectoine production increased from 1.56 to $2.67 \mathrm{mg} /$ $\mathrm{mL}$ in flask. In fermentor, the ectoine production reached $25.1 \mathrm{~g} / \mathrm{L}$ in $24 \mathrm{~h}$, with a productive yield of $4048 \mathrm{mg} / \mathrm{g} \mathrm{DCW}$, which is the highest value ever reported. The cells can be used for at least 3 rounds and a total yield of $63.4 \mathrm{~g}$ ectoine was obtained using one litre cells. Our study herein provided a feasible biosynthesis process of ectoine with potential applications in largescale industrial production.

\section{Methods}

\section{Bacterial strains and media}

H. elongata DSM 2581 (CGMCC No.1.6329) was grown aerobically in Luria-Bertani (LB) medium consisting of $1.0 \%$ tryptone, $0.5 \%$ yeast extract, and $1 \% \mathrm{NaCl}$, modified by the addition of $\mathrm{NaCl}$ at a final concentration of $15 \%$ (wt/vol). E. coli DH5 $\alpha$ was used as a host in general gene cloning and the construction of recombinant plasmids. E. coli K12/BW25113 (rrnB3 $\Delta$ lacZ4787 hsdR514 $\triangle(\operatorname{araBAD}) 567 \Delta($ rhaBAD $) 568 \mathrm{rph}-1)$ was used as the host strain for protein expression and ectoine production. LB medium was used for growing $E$. coli cells. A defined medium (DM) was used for fed-batch cultures. This medium contains (per litre) $10 \mathrm{~g}$ glucose, $8 \mathrm{~g}$ of $\left(\mathrm{NH}_{4}\right)_{2} \mathrm{HPO}_{4}, 13.3 \mathrm{~g}$ of $\mathrm{KH}_{2} \mathrm{PO}_{4}, 1.2 \mathrm{~g}$ of $\mathrm{MgSO}_{4} \cdot 7 \mathrm{H}_{2} \mathrm{O}$, $1.7 \mathrm{~g}$ of citric acid, and $10 \mathrm{~mL}$ of a trace metal solution that contains (per litre of $5 \mathrm{M} \mathrm{HCl}$ ) $10 \mathrm{~g}$ of $\mathrm{FeSO}_{4}$. $7 \mathrm{H}_{2} \mathrm{O}, 2.25 \mathrm{~g}$ of $\mathrm{ZnSO}_{4} \cdot 7 \mathrm{H}_{2} \mathrm{O}, 1 \mathrm{~g}$ of $\mathrm{CuSO}_{4} \cdot 5 \mathrm{H}_{2} \mathrm{O}$, $0.5 \mathrm{~g}$ of $\mathrm{MnSO}_{4} \cdot 5 \mathrm{H}_{2} \mathrm{O}, 0.23 \mathrm{~g}$ of $\mathrm{Na}_{2} \mathrm{~B}_{4} \mathrm{O}_{7} \cdot 10 \mathrm{H}_{2} \mathrm{O}, 2 \mathrm{~g}$ of $\mathrm{CaCl}_{2} \cdot 2 \mathrm{H}_{2} \mathrm{O}$, and $0.1 \mathrm{~g}$ of $\left(\mathrm{NH}_{4}\right)_{6} \mathrm{MO}_{7} \mathrm{O}_{24}$. The 
antibiotic ampicillin $(100 \mathrm{mg} / \mathrm{L})$ was used to maintain the heterologous plasmid in the genetically modified strain.

\section{Molecular biological methods}

Standard methods were used for genomic DNA and plasmid DNA extraction, PCR, ligation, plasmid construction, and transformation [29]. The Pfu DNA polymerase, restriction endonucleases, T4 DNA ligase and vector pMD19-T Simple were purchased from Takara Bio (Takara Biotechnology dalian Co. Ltd., China). The vector pMD19-T Simple was used for cloning of PCR products and $\mathrm{pBAD} / \mathrm{HisA}$ (Invitrogen, USA) was used for gene expression.

The ect $A B C$ gene cluster was amplified by PCR using genomic DNA extracted from $H$. elongata DSM 2581 as the template and primers P1 and P2 as follows: P1, 5'CCTAGCTAGCATGAACGCAACCACAGAGCCCTT TA-3'; P2， 5'-CCGGAATTCTTACAGCGGCTTCTG GTCGTCGGCT-3' (NheI and EcoRI sites are in italics). The full length ectoine operon containing the genes ect $A$, ect $B$ and ect $C$ was amplified without any terminator, operator, or promoter region. The PCR products were ligated into the cloning vector pMD19$T$ Simple and verified by sequencing. The recombinant vector was transformed into E. coli $\mathrm{DH} 5 \alpha$. The NheI$E c o R I$ fragment from the recombinant cloning vector containing the ect $A B C$ gene cluster was recloned into the expression plasmid $\mathrm{pBAD} / \mathrm{His}$ A under the control of the ara promoter. The resulting vector pBADectABC was transformed into E. coli BW25113.

\section{Protein expression and identification}

The recombinant strain $\mathrm{BW}$ (pBAD-ectABC) was grown at $37^{\circ} \mathrm{C}$ in LB broth with ampicillin. When the optical density of the culture at $600 \mathrm{~nm}$ reached 0.6, L-arabinose was added at a final concentration of $0.1 \%$ and incubated at $30^{\circ} \mathrm{C}$ for $6 \mathrm{~h}$. The cells were harvested by centrifugation and resuspended in $50 \mathrm{mM}$ of potassium phosphate buffer (pH 7.0). The cell suspension was sonicated (Soniprep 150 sonifier) and centrifuged $(12,000 \times \mathrm{g}, 10 \mathrm{~min})$. The supernatant was subjected to SDS-PAGE analysis. For mass spectrometric protein identification, bands of interest were excised and submitted to in-gel reduction, alkylation, and digestion with bovine trypsin (12.5 ng/ $\mu \mathrm{l}$, sequencing grade; Roche Applied Science) as previously described by Sechi and Chait [30]. Afterward, the trypsinized peptides were analysed on an Applied Biosystems 4700 Proteomic Analyzer (Applied Biosystems, Framingham, MA) as previously described [31]. The resulting MS and MS/MS data were analyzed and peak lists were generated using GPS Explorer 3.5 (Applied Biosystems) and were further searched using MASCOT 2.0 search engine (MatrixScience, London,
U.K.) against SwissProt protein sequence database download in Dec, 2014 from NCBI.

\section{Bioreactor cultivation}

Precultures of recombinant strain BW (pBAD-ectABC) were prepared in shaking flasks $\left(30^{\circ} \mathrm{C}, 200 \mathrm{rpm}\right)$ with $\mathrm{LB}$ medium containing ampicillin. Fed-batch cultivations were performed in a 6.6 litre jar fermentor (Bioflo 3000; New Brunswick Scientific Co., Edison, N.J.) containing 2.7 litres of $\mathrm{DM}$ at $30^{\circ} \mathrm{C}$. The $\mathrm{pH}$ was controlled at $7.0 \pm$ 0.05 by automatic feeding of $25 \%(\mathrm{v} / \mathrm{v}) \mathrm{NH}_{4} \mathrm{OH}$. The dissolved oxygen concentration was maintained above $20 \%$ air saturation by supplying air at $1 \mathrm{vvm}$ (air volume/ working volume/minute) and by automatically controlling the agitation speed up to $1000 \mathrm{rpm}$. The feeding solution contained $500 \mathrm{~g}$ of glucose and $10 \mathrm{~g}$ of $\mathrm{MgSO}_{4}$. $7 \mathrm{H}_{2} \mathrm{O}$ per litre was added periodically after glucose depletion. Expression of ectoine genes were induced for 8 hours by adding $\mathrm{L}$-arabinose to the final concentration of $1 \mathrm{~g} / \mathrm{L}$ when the $\mathrm{OD}_{600}$ value had reached 30 .

\section{Bioconversion conditions}

After induction, cells were collected from shaking flask cultures by centrifugation at $6,000 \times \mathrm{g}$ for $20 \mathrm{~min}$, washed with $0.85 \% \mathrm{NaCl}$ solution twice, and then resuspended in the reaction mixture containing $100 \mathrm{mM}$ sodium phosphate buffer ( $\mathrm{pH}$ 7.0), $50 \mathrm{mM}$ sodium aspartate, $50 \mathrm{mM} \mathrm{KCl}$, and $100 \mathrm{mM}$ glycerol to form a cell suspension $\left(\mathrm{OD}_{600 \mathrm{~nm}}=5\right)$. The bioconversion reactions were performed using cell suspensions in 100-mL flasks in which the final liquid volume was $30 \mathrm{~mL}$ at $30^{\circ} \mathrm{C}$ and $200 \mathrm{rpm}$ on a rotary shaker for $24 \mathrm{~h}$.

To optimize the component of reaction mixture, various concentrations of sodium aspartate (50, 100, 200 and $300 \mathrm{mM}$ ) were compared in bioconversion test. $\mathrm{K}^{+}$ has been reported that can improve the activity and stability of ectB [28], so various concentrations of $\mathrm{KCl}(0$, 50, 100, 200 and $300 \mathrm{mM}$ ) were added into the reaction mixture to investigate the effect on ectoine production. To evaluate the effect of temperature on ectoine bioconversion, the reactions were performed at $25,30,35$ and $40^{\circ} \mathrm{C}$ at $\mathrm{pH}$ 7.0. To estimate the effect of $\mathrm{pH}$, the reaction mixture were adjusted to $\mathrm{pH}$ levels of 6.0, 6.5, 7.0, 7.5 , and 8.0 , and incubated at $30^{\circ} \mathrm{C}$.

The bioconversion of ectoine was also carried out in a fermentor. Cells after induction from a fed-batch fermentation were harvested by centrifugation at $6,000 \times \mathrm{g}$ for $20 \mathrm{~min}$, washed with $0.85 \% \mathrm{NaCl}$ solution twice, and then resuspended in the reaction mixture containing $100 \mathrm{mM}$ sodium phosphate buffer (pH 7.0), $200 \mathrm{mM}$ sodium aspartate, $200 \mathrm{mM}$ glycerol and $100 \mathrm{mM} \mathrm{KCl}$ to form a cell suspension $\left(\mathrm{OD}_{600 \mathrm{~nm}}=20\right)$. Three litres of cell suspension was added into a 6.6 litre fermentor. $\mathrm{NH}_{4} \mathrm{OH}(2 \mathrm{M})$ and $\mathrm{HCl}(2 \mathrm{M})$ were used to keep the $\mathrm{pH}$ 
at $7.0 \pm 0.05$. The reaction was performed at $30^{\circ} \mathrm{C}$ with agitation speed of $600 \mathrm{rpm}$ and the aeration rate at $1 \mathrm{vvm}$. The residual aspartate and glycerol were monitored by HPLC. When the substrates were consumed, feed solution containing $2 \mathrm{M}$ sodium aspartate, $2 \mathrm{M}$ glycerol and $100 \mathrm{mM} \mathrm{KCl}$ was added periodically according to the rate of substrate consumption. Subsequently, the cells were reharvested by centrifugation and a second round of synthesis was performed in the same reaction mixture. This process was repeated for two rounds.

\section{Cell biomass measurement}

Biomass concentrations were estimated by measuring the optical density at $600 \mathrm{~nm}\left(\mathrm{OD}_{600}\right)$. The dry cell weight $(\mathrm{DCW})$ was calculated on the basis of $\mathrm{OD}_{600}(1 \mathrm{OD} / \mathrm{mL}=$ $0.31 \mathrm{~g} \mathrm{DCW} / \mathrm{L})$. Glucose concentrations were measured by a SBA-40E biosensor analyser (Institute of Biology, Shandong Province Academy of Sciences, China).

\section{HPLC analytical methods}

For the identification of intracellular ectoine, cells were harvested by centrifugation and freeze-dried. Approximately $20 \mathrm{mg}$ of cell material was extracted according to the method of Bligh and Dyer [32]. The extracellular concentration of ectoine was directly measured after dilution of the samples with acetonitrile/water $(70: 30 \mathrm{v} / \mathrm{v})$. The intracellular and extracellular samples were filtered through a 0.22 -um pore size membrane filter and then analysed by isocratic HPLC (Agilent 1260 series, Hewlett-Packard) using an Agilent ZOBAX NH2 column $(2.6 \times 250 \mathrm{~mm}, 5 \mathrm{um})$ with acetonitrile/water $(70: 30 \mathrm{v} / \mathrm{v})$ at a flow rate of $1 \mathrm{~mL} / \mathrm{min}$ as the mobile phase. UV detection at $210 \mathrm{~nm}$ was used to measure ectoine, and simultaneously a refraction index detection system was used to measure glycerol at $35^{\circ} \mathrm{C}$. The aspartate concentration was determined by reversed phase HPLC according to an Agilent method [33]. The samples were automatically derivatized with OPA and then injected into a Zorbax Eclipse-AAA column $(4.6 \times 75 \mathrm{~mm}, 3.5 \mu \mathrm{m})$ at $40^{\circ} \mathrm{C}$ with detection at $338 \mathrm{~nm}$. The retention times of ectoine, glycerol and aspartate were determined by using commercially available samples (Sigma).

\section{LC-MS analysis of ectoine}

The ectoine purified by HPLC on an Agilent ZOBAX $\mathrm{NH}_{2}$ column described above was indentified using an Agilent 1260/6460 high performance liquid chromatography/triple quadrupole mass spectrometer (Agilent, USA) using ESI source in positive ionization mode. The chromatographic separation was carried out using a ZORBAX SB-Aq $(100 \mathrm{~mm} \times 2.1 \mathrm{~mm}, 3.5 \mu \mathrm{m}$, Agilent, USA) at $30^{\circ} \mathrm{C}$. The mobile phases were the mixture of 95\% methanol and 5\% water (containing $0.1 \%$ formic acid) (v/v) under isocratic elution program at a flow rate of $0.2 \mathrm{~mL} / \mathrm{min}$. For the LC-MS analysis, the mass scan ranged from $m / z 80$ to 400 . For the LC-MS/MS analysis, the product ion scan of $\mathrm{m} / \mathrm{z} 143$ was performed with collision energy of $17 \mathrm{~V}$. The fragmentor voltage was $110 \mathrm{~V}$. The capillary voltage and atomizing gas pressure were $4.0 \mathrm{kV}$ and $35 \mathrm{psi}$, respectively. The flow rate of drying gas was $12 \mathrm{~mL} / \mathrm{min}$ and the temperature of solvent removal was $350^{\circ} \mathrm{C}$. Nitrogen was used as collision gas.

\section{Competing interests}

The authors declare that they have no competing interests.

\section{Authors' contributions}

ZYD and SZ conceived and designed the experiments. YZH and JG performed the experiments. YZH, JG and HYY analyzed the data. YZH and SZ wrote the manuscript. YT, SZ and ZYD reviewed and revised the manuscript. All authors read and approved the final manuscript.

\section{Acknowledgements}

This work was supported by the National Natural Science Foundation of China (31100066) and the National High Technology Research and Development Program ("863"Program: 2012AA02A703).

\section{Author details}

'State Key Laboratory of Microbial Resources, Institute of Microbiology, Chinese Academy of Sciences, Beijing 100101, China. ${ }^{2}$ University of Chinese Academy of Sciences, Beijing 100049, China. ${ }^{3}$ Department of Industrial Microbiology and Biotechnology, Institute of Microbiology, Chinese Academy of Sciences, Beijing 100101, China.

Received: 26 January 2015 Accepted: 1 April 2015

Published online: 15 April 2015

\section{References}

1. Oren A, Heldal M, Norland S, Galinski EA. Intracellular ion and organic solute concentrations of the extremely halophilic bacterium Salinibacter ruber. Extremophiles. 2002;6:491-8.

2. Roberts MF. Osmoadaptation and osmoregulation in archaea: update 2004. Front Biosci. 2004;9:1999-2019.

3. Kempf B, Bremer E. Uptake and synthesis of compatible solutes as microbial stress responses to high-osmolality environments. Arch Microbiol. 1998;170:319-30.

4. Galinski EA, PFEIFFER HP, TRÜPER HG. 1, 4, 5, 6-Tetrahydro-2-methyl-4pyrimidinecarboxylic acid. Eur J Biochem. 1985;149:135-9.

5. Lentzen G, Schwarz T. Extremolytes: Natural compounds from extremophiles for versatile applications. Appl Microbiol Biot. 2006;72:623-34.

6. Da Costa MS, Santos H, Galinski EA. An overview of the role and diversity of compatible solutes in Bacteria and Archaea. Adv Biochem Eng Biotechnol. 1998:61:117-53.

7. Graf R, Anzali S, Buenger J, Pfluecker F, Driller $H$. The multifunctional role of ectoine as a natural cell protectant. Clin Dermatol. 2008;26:326-33.

8. Jorg Kunte H, Lentzen G,A, Galinski E. Industrial production of the cell protectant ectoine: protection mechanisms, processes, and products. Curr Biotechnol. 2014;3:10-25.

9. Abdel-Aziz H, Wadie W, Abdallah DM, Lentzen G, Khayyal MT. Novel effects of ectoine, a bacteria-derived natural tetrahydropyrimidine, in experimental colitis. Phytomedicine. 2013;20:585-91.

10. Pastor JM, Salvador M, Argandona M, Bernal V, Reina-Bueno M, Csonka LN, et al. Ectoines in cell stress protection: uses and biotechnological production. Biotechnol Adv. 2010;28:782-801.

11. Cánovas D, Vargas C, Iglesias-Guerra F, Csonka LN, Rhodes D, Ventosa A et al. Isolation and characterization of salt-sensitive mutants of the moderate halophile Halomonas elongata and cloning of the ectoine synthesis genes. J Biol Chem. 1997;272:25794-801.

12. Peters $P$, Galinski EA, Truper HG. The Biosynthesis of Ectoine. FEMS Microbiol Lett. 1990;71:157-62.

13. Schwibbert K, Marin-Sanguino A, Bagyan I, Heidrich G, Lentzen G, Seitz H, et al. A blueprint of ectoine metabolism from the genome of the industrial 
producer Halomonas elongata DSM 2581 T. Environ Microbiol. 2011;13:1973-94.

14. Sauer T, Galinski EA. Bacterial milking: a novel bioprocess for production of compatible solutes. Biotechnol Bioeng. 1998;57:306-13.

15. Fallet C, Rohe P, Franco-Lara E. Process optimization of the integrated synthesis and secretion of ectoine and hydroxyectoine under hyper/ hypo-osmotic stress. Biotechnol Bioeng. 2010;107:124-33.

16. Schubert T, Maskow T, Benndorf $D$, Harms $H$, Breuer U. Continuous synthesis and excretion of the compatible solute ectoine by a transgenic, nonhalophilic bacterium. Appl Environ Microbiol. 2007:73:3343-7.

17. Zhang LH, Lang YJ, Nagata S. Efficient production of ectoine using ectoine-excreting strain. Extremophiles. 2009;13:717-24.

18. Bestvater T, Louis P, Galinski EA. Heterologous ectoine production in Escherichia coli: by-passing the metabolic bottle-neck. Saline Systems. 2008:4:12.

19. Stöveken N, Pittelkow M, Sinner T, Jensen RA, Heider J, Bremer E. A specialized aspartokinase enhances the biosynthesis of the osmoprotectants ectoine and hydroxyectoine in Pseudomonas stutzeri A1501. J Bacteriol. 2011;193:4456-68.

20. Anbu Rajan L, Joseph TC, Thampuran N, James R, Ashok Kumar K, Viswanathan $C$, et al. Cloning and heterologous expression of ectoine biosynthesis genes from Bacillus halodurans in Escherichia coli. Biotechnol Lett. 2008;30:1403-7.

21. Zhu D, Liu J, Han R, Shen G, Long Q, Wei X, et al. Identification and characterization of ectoine biosynthesis genes and heterologous expression of the ectABC gene cluster from Halomonas sp. QHL1, a moderately halophilic bacterium isolated from Qinghai Lake. J Microbiol. 2014:52:139-47.

22. Becker J, Schafer R, Kohlstedt M, Harder BJ, Borchert NS, Stoveken N, et al. Systems metabolic engineering of Corynebacterium glutamicum for production of the chemical chaperone ectoine. Microb Cell Fact. 2013;12:110.

23. Eilert E, Kranz A, Hollenberg CP, Piontek M, Suckow M. Synthesis and release of the bacterial compatible solute 5-hydroxyectoine in Hansenula polymorpha. J Biotechnol. 2013;167:85-93.

24. Duetz WA, van Beilen JB, Witholt B. Using proteins in their natural environment: potential and limitations of microbial whole-cell hydroxylations in applied biocatalysis. Curr Opin Biotechnol. 2001;12:419-25.

25. Blattner FR, Plunkett 3rd G, Bloch CA, Perna NT, Burland V, Riley M, et al. The complete genome sequence of Escherichia coli K-12. Science. 1997;277:1453-62.

26. Jebbar M, Talibart R, Gloux K, Bernard T, Blanco C. Osmoprotection of Escherichia coli by ectoine: uptake and accumulation characteristics. J Bacteriol. 1992;174:5027-35.

27. Göller K, Ofer A, Galinski EA. Construction and characterization of an $\mathrm{NaCl}$ sensitive mutant of Halomonas elongata impaired in ectoine biosynthesis. FEMS Microbiol Lett. 1998;161:293-300.

28. Ono H, Sawada K, Khunajakr N, Tao T, Yamamoto M, Hiramoto M, et al. Characterization of biosynthetic enzymes for ectoine as a compatible solute in a moderately halophilic eubacterium, Halomonas elongata. J Bacteriol. 1999;181:91-9.

29. Sambrook J, Russell DW. Molecular Cloning: A Laboratory Manual. 3rd ed. New York: Cold Spring Harbor Laboratory, Cold Spring Harbor; 2001.

30. Sechi S, Chait BT. Modification of cysteine residues by alkylation. A tool in peptide mapping and protein identification. Anal Chem. 1998;70:5150-8.

31. Liu H, Luo Y, Han J, Wu J, Wu Z, Feng D, et al. Proteome reference map of Haloarcula hispanica and comparative proteomic and transcriptomic analysis of polyhydroxyalkanoate biosynthesis under genetic and environmental perturbations. J Proteome Res. 2013;12:1300-15.

32. Bligh EG, Dyer WJ. A rapid method of total lipid extraction and purification. Can J Biochem Physiol. 1959;37:911-7.

33. Mengerink Y, Kutlán D, Tóth F, Csámpai A, Molnár-Perl I. Advances in the evaluation of the stability and characteristics of the amino acid and amine derivatives obtained with the o-phthaldialdehyde/3-mercaptopropionic acid and o-phthaldialdehyde/ $\mathrm{N}$-acetyl-L-cysteine reagents: High-performance liquid chromatography-mass spectrometry study. J Chromatogr A. 2002;949:99-124.

\section{Submit your next manuscript to BioMed Central and take full advantage of:}

- Convenient online submission

- Thorough peer review

- No space constraints or color figure charges

- Immediate publication on acceptance

- Inclusion in PubMed, CAS, Scopus and Google Scholar

- Research which is freely available for redistribution

Submit your manuscript at www.biomedcentral.com/submit 